\title{
ロール角保持状態でのラダー操作による横飛行経路制御*1 Lateral Flight-Path Control by Rudder Steering under Holding Roll Angle
}

\author{
野田讓 $* 2, * 3 \cdot$ 小林修*4 \\ Yuzuru NodA and Osamu KoBAYAshi
}

Key Words : Airplane, Flying Qualities, Flight-Path Control, Lateral-Directional Control

\begin{abstract}
Most airplanes use their ailerons to compensate the lateral displacement deviation from a reference flightpath. This study proposes a method of lateral flight-path control due to the rudder steering under constraint of automatic roll angle hold. This control method is estimated analytically to produce quicker lateral displacement response than the control due to aileron. Then, experiments using a flight simulator are carried out to evaluate the control characteristics on the task of holding the flight path. The pilot's evaluation results show that, the rudder steering method gives better flying qualities than aileron steering method. Furthermore, as the more practical control measures, the mixture type of method is worked out, which is transferred from aileron steering to rudder steering depending on the lateral displacement deviation from a reference flight-path.
\end{abstract}

\section{1. は じめに}

本論文は, 航空機が目標とする横飛行経路を保持する飛行 タスクにおける新しい操縦方式の試みについて検討してい る. 対象とする航空機は直接横力制御 (Direct Side-Force Control) の機能を有しない通常の航空機であり, 有人機で も無人機でも良いが，いずれも人間パイロットが機首前方 の外部視界を見ながら操縦することを想定している．つま り，無人機の場合は关の機首に取り付けられたカメラから の映像が地上コックピットのモニターに映し出され，光の 映像を見ながら人間パイロットが操縦することを想定して いる．また，パイロットが横飛行経路保持タスクを実施する ときは, ILS (Instrument Landing System) 着陸方式に おけるローカライザのような目標とする横飛行経路がヘッ ドアップディスプレイ (Head-up display , HUD) などを 用いてパイロットに視覚情報として示されているものとし ている。

さて, 通常の航空機における横飛行経路保持タスクは, エ ルロン操作でもってロール角を変更し, 弚れに伴う旋回運 動の結果として得られる機首方位変化を制御しながら実施 される . 以下 , この操縦方式を「エルロン方式」と称する ことにする．この方式においては，ほぼ横滑りゼロとみな せる釣り合い旋回をしながら飛行しているとみなせること が特徵の一つであるが, もう一つの特徵として, エルロン

\footnotetext{
*1 C) 2006 日本航空宇宙学会

平成 17 年 10 月 12 日, 第 43 回飛行機シンポジウムにおいて一 部発表. 平成 18 年 3 月 24 日原稿受理

$* 2$ 東海大学大学院工学研究科航空宇宙学専攻

*3 現 全日本空輸 (株)

$* 4$ 東海大学工学部航空宇宙学科
}

操舵入力から横飛行経路の変位出力までの位相遅れが著し く大きいために, 横飛行経路保持に際してパイロットが位 相進み操作をしなければならず, 結果としてロール角の切 り返しが繰り返される状況を生み出していることが挙げら れる. 従って , 後者の特徵である応答の位相遅れが緩和さ れれば, 弚れに伴って横飛行経路保持タスクにおいてパイ ロットに要求される進み操作も緩和され, 操縦性の向上が 期待できる。

关こで, 横飛行経路保持タスクにおいて使用する舵面を， エルロンではなくラダーにしてみた場合の応答の位相遅れ について考えた . 通常の航空機では, ラダーのみを操舵す ると, 機首方位と横滑りの発生だけでなく，弚れに続き上反 角効果によって発生するロール運動 (Ruder-induced roll) が支配的になる .このロール運動はエルロン操舵に伴うロー ル運動よりも位相遅れがさらに大きいので，このままでは 操縦性を劣化させてしまう．㫕こで，エルロンでロール角 を自動的・機械的に保持しつつ，パイロットがラダーを操 作するケースを検討対象とする . 即ち，自動飛行制御シス テムのロール角保持モードを ON にした状態で, ラダーを 操作して横飛行経路タスクを行う. 以後, この操縦方式を 「ラダー方式」と称することにする．ロール角の発生を無 視できるラダー方式では, ラダー操舵が直接に機首方位と 横滑りの応答を発生させる. しかも, 关の横滑りにより発 生する横力は直接に横変位の加速度を与える .このように , このラダー方式ではエルロン方式よりも操舵入力から横変 位出力までの位相遅れが小さいこと, およびその結果とし て横飛行経路保持タスクでのパイロット操縦性の向上が期 待できる．

そこで, 本論文ではラダー方式のエルロン方式に対する 
第 1 表 機体モデルの有次元空力微係数 ${ }^{1)}$

\begin{tabular}{lll}
\hline$Y_{\beta}=-13.84\left(\mathrm{~m} / \mathrm{s}^{2}\right)$, & $L_{\beta}^{\prime}=-1.71\left(1 / \mathrm{s}^{2}\right)$, & $N_{\beta}^{\prime}=0.986\left(1 / \mathrm{s}^{2}\right)$ \\
$Y_{p}=0.218(\mathrm{~m} / \mathrm{s})$, & $L_{p}^{\prime}=-0.962(1 / \mathrm{s})$, & $N_{p}^{\prime}=-0.0632(1 / \mathrm{s})$ \\
$Y_{r}=0.811(\mathrm{~m} / \mathrm{s})$, & $L_{r}^{\prime}=0.271(1 / \mathrm{s})$, & $N_{r}^{\prime}=-0.215(1 / \mathrm{s})$ \\
$Y_{\delta \mathrm{a}}=0\left(\mathrm{~m} / \mathrm{s}^{2}\right)$, & $L_{\delta \mathrm{a}}^{\prime}=-1.72\left(1 / \mathrm{s}^{2}\right)$, & $N_{\delta \mathrm{a}}^{\prime}=0.0436\left(1 / \mathrm{s}^{2}\right)$ \\
$Y_{\delta \mathrm{r}}=2.795\left(\mathrm{~m} / \mathrm{s}^{2}\right)$, & $L_{\delta \mathrm{r}}^{\prime}=0.244\left(1 / \mathrm{s}^{2}\right)$, & $N_{\delta \mathrm{r}}^{\prime}=-0.666\left(1 / \mathrm{s}^{2}\right)$ \\
$U_{0}=89.55(\mathrm{~m} / \mathrm{s})$ & &
\end{tabular}

利点を解析的に理解するとともに，固定座席型フライトシ ミュレータを用いて基本的な効果や問題を調べる .さらに 弚れらの結果に基づき, 目標飛行経路からの逸脱量が大き いときはエルロン方式を, 乥して逸脱量が小さくなるとラ ダー方式に遷移していくより実用的な操縦システムを提案 し，フライトシミュレータで光の効果を検討した .

なお，エルロン方式とラダー方式とではパイロット操舵 入力によって動作する舵面が異なるものの，パイロットが 操舵入力を与えるために操作する装置はどちらも操縦輪と している．つまりラダー方式でのラダーも操縦輪を操作す ることによって動作する .これは操作方法の違いによる操 縦性への影響を除去する目的もあるが , 操縦輪操作 (手に よる操舵) の方がラダーペダル (足による操舵) に比べ精 密な操縦が可能であるという実用的な目的が主である．

以下，本研究で使用する航空機モデルを説明する．本論 文が扱っている横飛行経路保持タスクは光れほど激しい運 動を行うタスクではないので, 運動方程式として下記の線 形微小擾乱運動方程式 (1) を用いる.

$$
\begin{gathered}
\left|\begin{array}{ccc}
\left(U_{0} s-Y_{\beta}\right) & -\left(Y_{p} s+g\right) & -\left(Y_{r}-U_{0}\right) \\
-L_{\beta}^{\prime} & \left(s^{2}-L_{p}^{\prime} s\right) & -L_{r}^{\prime} \\
-N_{\beta}^{\prime} & -N_{p}^{\prime} s & \left(s-N_{r}^{\prime}\right)
\end{array}\right|\left|\begin{array}{c}
\beta(s) \\
\phi(s) \\
r(s)
\end{array}\right| \\
=\left|\begin{array}{c}
Y_{\delta \mathrm{a}} \\
L_{\delta \mathrm{a}}^{\prime} \\
N_{\delta \mathrm{a}}^{\prime}
\end{array}\right| \cdot \delta_{\mathrm{a}}(s)+\left|\begin{array}{c}
Y_{\delta \mathrm{r}} \\
L_{\delta \mathrm{r}}^{\prime} \\
N_{\delta \mathrm{r}}^{\prime}
\end{array}\right| \cdot \delta_{\mathrm{r}}(s)
\end{gathered}
$$

ここで， $\beta$ は横滑り角， $\phi$ はロール角,$r$ はヨーレート,$p$ はロールレート， $\delta_{*}$ は舵角 (添え字 * が a の場合はエルロ ン舵角，r の場合はラダ一舵角を表す)， $U_{0}$ は初期卜リム 状態での飛行速度, および $s$ はラプラス演算子である . ま

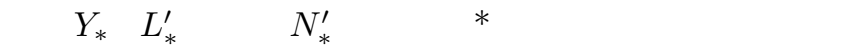
リングモーメントおよびヨーイングモーメントに関する有 次元空力微係数である . また , 航空機の空力特性值のモデ ルとして, 参考文献 1) に示されている P 2V-7 改・可変特性 研究機の安定軸基準の有次元空力微係数值を使用した . 光 の值を第 1 表に示す (ただし，本論文ではエルロン舵角の 符号を, 右翼後縁下げ/左翼後縁上げのとき正であるとし ている）. 初期卜リム飛行条件は, 飛行高度が約 $10,000 \mathrm{ft}$ $(3,048 \mathrm{~m})$, 光して飛行速度が $89.55 \mathrm{~m} / \mathrm{s}$ で水平直線飛行 時のものである .

\section{2. 操舵入力から横変位出力までの発生過程}

本章では, 式 (1) をさらに近似して , エルロン方式とラ ダー方式における横変位の発生過程の本質的な違いを明確 にする .

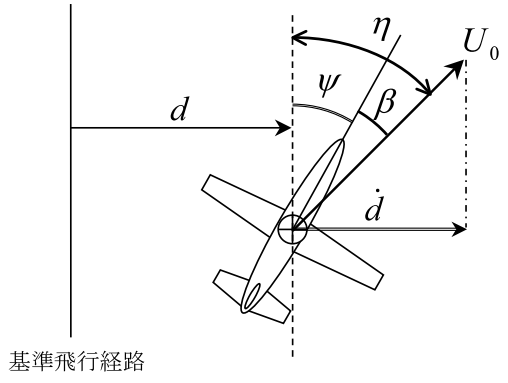

第 1 図 横方向の飛行パラメータ

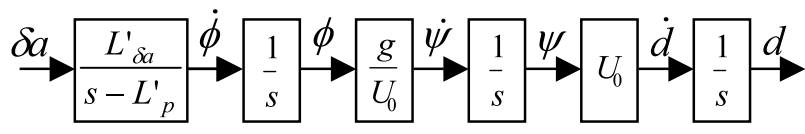

第 2 図 エルロン入力時の横変位発生過程

2.1 エルロン方式における横変位の発生過程 エルロ ン方式の場合, 航空機は常にエルロン操舵によって発生す るロール角に応じた釣り合い旋回 $(\beta=0)$ をしていると 近似的に仮定することができる．よって，横方向の運動方 程式 (1) は，次のように簡略化することができる .

$$
\left|\begin{array}{cc}
\left(s^{2}-L_{p}^{\prime} s\right) & -L_{r}^{\prime} \\
-N_{p}^{\prime} s & \left(s-N_{r}^{\prime}\right)
\end{array}\right|\left|\begin{array}{c}
\phi(s) \\
r(s)
\end{array}\right|=\left|\begin{array}{c}
L_{\delta \mathrm{a}}^{\prime} \\
N_{\delta \mathrm{a}}^{\prime}
\end{array}\right| \cdot \delta_{\mathrm{a}}(s)
$$

また，通常の航空機であれば $N_{p}^{\prime} \approx N_{\delta \mathrm{a}}^{\prime} \approx 0$ とみなせる ので, エルロン舵角 $\delta_{\mathrm{a}}$ に対するロールレート $p$ の伝達関数 は次のように表される .

$$
\frac{p(s)}{\delta_{\mathrm{a}}(s)}=\frac{L_{\delta \mathrm{a}}^{\prime}}{s-L_{p}^{\prime}}=\frac{-L_{\delta \mathrm{a}}^{\prime} / L_{p}^{\prime}}{\left(-1 / L_{p}^{\prime}\right) s+1}
$$

次に, 航空機が水平定常釣り合い旋回しているとき，旋 回角速度 $\dot{\psi}$ とロール角 $\phi$ との間には次の関係がある .

$$
\dot{\psi}=\frac{g}{U_{0}} \phi
$$

上式で求めた $\psi$ を時間積分すると方位角 $\psi$ が得られる . 光 の $\psi$ を用いて, 横変位速度 $\dot{d}$ は次式で表される（第 1 図 参照).

$$
\dot{d}=U_{0} \psi
$$

この $\dot{d}$ を時間積分することによって横変位 $d$ が求まる. 以 上のエルロン操舵から横変位速度発生までの過程をブロッ ク図に示したものが第 2 図である.

2.2 ラダー方式における横変位の発生過程とエルロン方 式との比較 ラダー方式の場合，ロール角保持機能によっ てロール角が完全にゼロに保持されていると仮定する（す なわち， $\phi=p=0)$. 従って ，このときの運動方程式 (1) は式 (6) のように近似できる .

$$
\left|\begin{array}{cc}
\left(U_{0} s-Y_{\beta}\right) & -\left(Y_{r}-U_{0}\right) \\
-N_{\beta}^{\prime} & \left(s-N_{r}^{\prime}\right)
\end{array}\right|\left|\begin{array}{c}
\beta(s) \\
r(s)
\end{array}\right|=\left|\begin{array}{c}
Y_{\delta \mathrm{r}} \\
N_{\delta \mathrm{r}}^{\prime}
\end{array}\right| \cdot \delta_{\mathrm{r}}(s)
$$




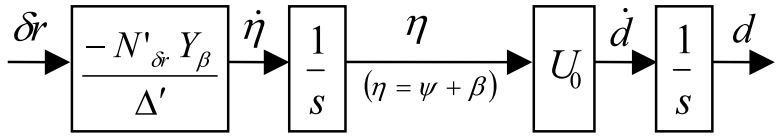

第 3 図 ラダー入力時の横变位発生過程

よって, ラダー舵角 $\delta_{\mathrm{r}}$ に対する横滑り角 $\beta$ の伝達関数は次 のようになる .

$$
\frac{\beta(s)}{\delta_{\mathrm{r}}(s)} \cong \frac{-N_{\delta \mathrm{r}}^{\prime} U_{0}}{\Delta^{\prime}}
$$

ただし， $\Delta^{\prime}$ は横方向運動の特性方程式の近似式であり，次

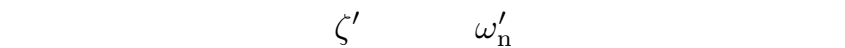
れる減衰比と固有角振動数の近似值である.

$$
\begin{aligned}
\Delta^{\prime} & =U_{0} s^{2}-\left(U_{0} N_{r}^{\prime}+Y_{\beta}\right) s+Y_{\beta} N_{r}^{\prime}-N_{\beta}^{\prime}\left(Y_{r}-U_{0}\right) \\
& =U_{0}\left(s^{2}+2 \zeta^{\prime} \omega_{\mathrm{n}}^{\prime} s+\omega_{\mathrm{n}}^{\prime 2}\right)
\end{aligned}
$$

また, ラダー舵角 $\delta_{\mathrm{r}}$ に対する旋回角速度 $\dot{\psi}$ の伝達関数は 次式となる .

$$
\frac{\dot{\psi}(s)}{\delta_{\mathrm{r}}(s)}=\frac{r(s)}{\delta_{\mathrm{r}}(s)} \cong \frac{N_{\delta \mathrm{r}}^{\prime}\left(U_{0} s-Y_{\beta}\right)}{\Delta^{\prime}}
$$

式 (7) と (8) より横方向の飛行経路角 $\eta$ は次式で表される (第 1 図参照).

$$
\begin{aligned}
\frac{\eta(s)}{\delta_{\mathrm{r}}(s)} & =\frac{\psi(s)+\beta(s)}{\delta_{\mathrm{r}}(s)} \\
& =\left(\frac{\dot{\psi}(s)}{\delta_{\mathrm{r}}(s)} \cdot \frac{1}{s}+\frac{\beta(s)}{\delta_{\mathrm{r}}(s)}\right) \\
& =\frac{-N_{\delta \mathrm{r}}^{\prime} Y_{\beta}}{s \cdot \Delta^{\prime}}
\end{aligned}
$$

さらに, 横変位速度 $\dot{d}$ は $\eta$ を用いて次式で表される。

$$
\dot{d} \approx U_{0} \eta
$$

このd時間積分することによって横変位 $d$ が求まる . 以 上のラダー操舵から横变位速度発生までの過程のブロック 図を第 3 図に示す。

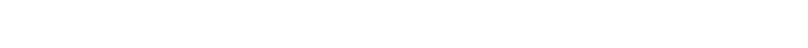
による横変位発生までの過程を比較してみる. 第 2 図の工 ルロン操舵入力では, 1 次遅れ要素に続いて純粋な積分要素 3 個を通過して横変位が発生する.これに対して, 第 3 図の ラダー操舵入力では, 2 次遅れ要素の後に純粋な積分要素 2 個を経て横变位が発生する.ここで，機体応答に対する 1 次遅れ要素と 2 次遅れ要素の違いの程度を調べてみる. 第 4 図に, 本研究で使用する航空機モデルにおける第 2 図中の 1 次遅れ要素 (時定数の近似值 $=-1 / L_{p}^{\prime}=1.04 \mathrm{~s}$ ) と第 3 图 中の 2 次遅れ要素 (固有角振動数の近似值 $\omega_{\mathrm{n}}^{\prime}=1.01 \mathrm{rad} / \mathrm{s}$,

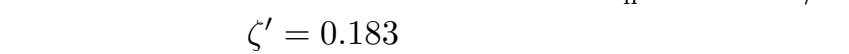
に対するステップ応答を示す.この応答の比較から， 1 次 遅れ要素と 2 次遅れ要素の速応性に大差ないことがわかる.

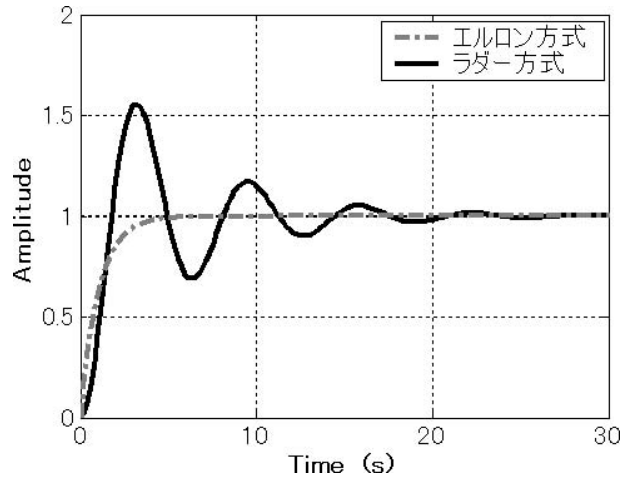

第 4 図 ステップ応答の比較

さらに , 相対的に高周波成分からなるこれらの多少の差異 は光の後に続くローパス・フィルタである積分要素を通過 するとさらに薄れていくことを考えれば， 1 次遅れ要素と 2 次遅れ要素の応答への差異は無視できよう . したがって， ラダー方式の方が操舵入力から横変位発生までに積分要素 が一つ少ないことが, 両方式の差異の特徵であることがわ かった .このことから横変位を制御する横飛行経路保持夕 スクにおいて , パイロットにとってラダー方式の方が位相 進み補償操作が少なくて済み，操縦が楽になる可能性があ ると推測される .

\section{3. 航空機モデルおよび飛行制御システムモデル}

3.1 航空機モデル 第 1 章にて述べたように本論文で は, 航空機の空力特性モデルとして, 参考文献 1) に示され ている P $2 \mathrm{~V}-7$ 改・可変特性研究機の安定軸基準の有次元空 力微係数值を使用した (第 1 表参照). 航空機の運動方程 式には式 (1)に示した線形微小擾乱運動方程式を使用する . この機体の特性多項式 $\Delta_{\text {lat }}$ は次式 (11) に示すように $s$ に 関する 4 次式となる .

$$
\Delta_{\text {lat }}=\left\{s+\left(1 / \tau_{\mathrm{S}}\right)\right\}\left\{s+\left(1 / \tau_{\mathrm{R}}\right)\right\}\left(s^{2}+2 \zeta_{\mathrm{d}} \omega_{\mathrm{nd}} s+\omega_{\mathrm{nd}}^{2}\right)
$$

また，この飛行条件での運動モード特性值は以下の通りで ある .

・ダッチロール・モード

減衰率 $\zeta_{\mathrm{d}}=0.100$, 固有角振動数 $\omega_{\mathrm{nd}}=1.07 \mathrm{rad} / \mathrm{s}$ ・ロール・モード

時定数 $\tau_{\mathrm{R}}=0.90 \mathrm{~s}$

・スパイラル・モード

時定数 $\tau_{\mathrm{S}}=117.1 \mathrm{~s}$

3.2 飛行制御システムモデル ラダー方式の場合は自 動的にロール角を保持する機能が飛行制御システムとして 組み込まれていることを前提としている．また，一般にラ ダ一操舵を行うと, エルロン操舵時と比較して, ダッチロー ル・モードの応答成分が大きく励起されることを考慮に入 れて、ヨーダンパを用意しておいた .このヨーダンパは，両 方式共通のシステムとしている.以下, 兴の飛行制御シス テムを第 5 図に示すブロック線図を参照しながら説明する . 


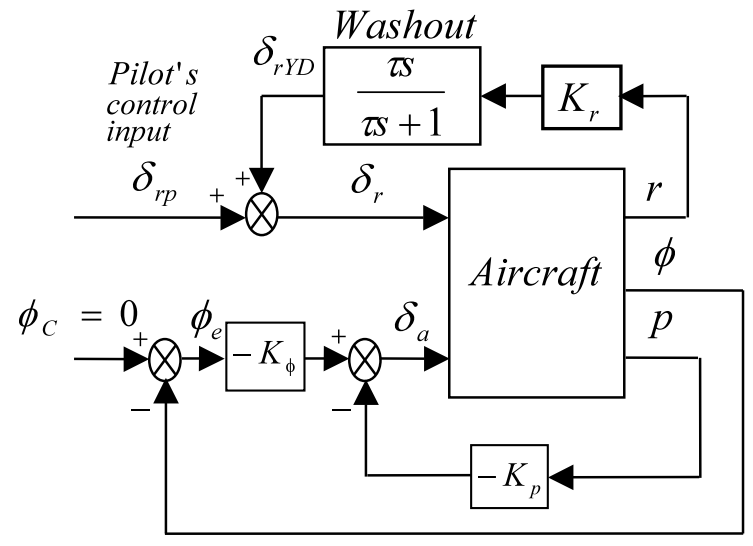

第 5 図飛行制御システム

第 2 表 飛行制御システムのゲイン一覧 (基礎実験)

\begin{tabular}{lllll}
\hline & $K_{\phi}$ & $K_{p}$ & \multicolumn{1}{c}{$K_{r}$} & $\tau_{r}(\mathrm{~s})$ \\
\hline エルロン方式 & 0 & 0 & 0 & 0 \\
ラダー方式 & 0.8 & 3 & 0 & 0 \\
エルロン方式-YD & 0 & 0 & 1.031 & 4.8 \\
ラダー方式-YD & 0.8 & 3 & 0.726 & 2.09 \\
\hline
\end{tabular}

第 3 表 横方向の飛行パラメータの比較 (基礎実験)

\begin{tabular}{llcccc}
\hline & $\zeta_{\mathrm{d}}$ & $\begin{array}{c}\omega_{\mathrm{nd}} \\
(\mathrm{rad} / \mathrm{s})\end{array}$ & $\begin{array}{c}\zeta_{\mathrm{d}} \omega_{\mathrm{nd}} \\
(\mathrm{rad} / \mathrm{s})\end{array}$ & $|\phi / \beta|_{\mathrm{d}}$ & $\phi_{\mathrm{ss}} / \delta_{\mathrm{r}}$ \\
\hline エルロン方式 & 0.10 & 1.07 & 0.11 & 1.04 & -0.83 \\
ラダー方式 & 0.18 & 1.03 & 0.19 & 0.28 & -0.01 \\
エルロン方式-YD & 0.4 & 0.95 & 0.38 & 1.24 & -0.83 \\
ラダー方式-YD & 0.4 & 0.93 & 0.37 & 0.31 & -0.01 \\
\hline
\end{tabular}

ロール角保持システムは, ロール角をロール角コマンド $\phi_{\mathrm{C}}=0$ に保持するループ (ゲイン $\left.K_{\phi}\right)$ とロールダンパの ループ (ゲイン $K_{p}$ ) から構成される . また , ダッチロー ル・モード抑制を目的とするヨーダンパ (ゲイン $K_{r}$ ) の ループ内にハイパス・フィルタとしてウォッシュアウト要 素 (時定数 $\tau_{r}$ ) を組み込んでいる．これは，ヨーダンパが ダッチロール・モード振動による相対的に高周波域のヨー レート応答成分には反応するが, 旋回時の低周波域のヨー レート応答成分には反応をしないようにすることで, 旋回 操縦性への悪影響を与えないようにするためのものである 本研究に供するロール角保持システムとして , ゲイン設 定 ( $K_{\phi}$ と $K_{p}$ の組み合わせ ) を用意した . また，ヨーダン パは両方式ともにダッチロール・モードの減衰率 $\zeta_{\mathrm{d}}$ が 0.4 になるように設計して用意した . 第 2 表に光れらゲイン等 の設定値をまとめて示す .

第 3 表にエルロン方式とラダー方式の場合におけるダッ チロール・モードの減衰率 $\zeta_{\mathrm{d}}$ と固有角振動数 $\omega_{\mathrm{nd}}$, 横滑 り角とロール角における光れ光れのダッチロール・モード 成分の振幅比 $|\phi / \beta|_{\mathrm{d}}$ ，およびラダーステップ入力に対する ロール角 $\phi$ の定常值の比 $\phi_{\mathrm{ss}} / \delta_{\mathrm{r}}$ を示す . 表中の「エルロン 方式-YD」の「YD」はヨーダンパが作動している状態で あることを意味する .なお , $|\phi / \beta|_{\mathrm{d}}$ の值は次の近似式 ${ }^{1)} よ$ り求めた .

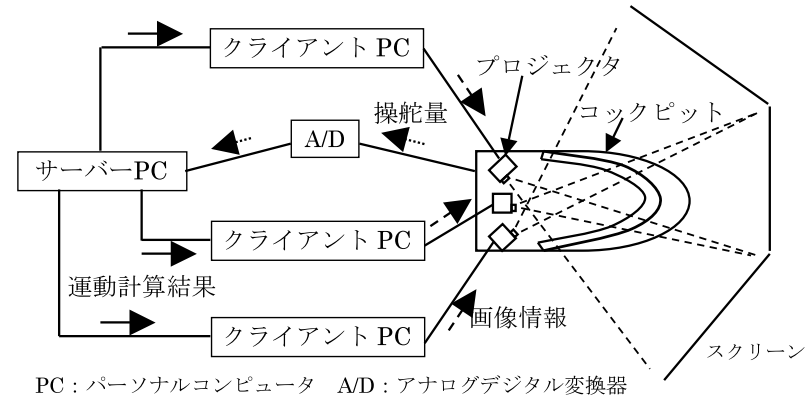

第6図 フライトシミュレータの構成

$$
|\phi / \beta|_{\mathrm{d}} \cong\left(\left|-L_{\beta}^{\prime}\right| / \omega_{\text {nd }}^{2}\right) / \sqrt{1+\left\{1 /\left(\tau_{\mathrm{R}} \omega_{\mathrm{nd}}\right)\right\}^{2}}
$$

\section{4. フライトシミュレータ実験}

実施したフライトシミュレータ実験は二つに大きく分け られる．一つは, エルロン方式とラダー方式の基本的な特 性の違いを調べる基礎実験であり，もう一つは，㫕れらの 結果を受けて提案する方式 (エルロン方式とラダー方式と を組み合わせたより実用に近い方式) の有効性についての 応用実験である .これらの詳細を述べる前に，シミュレー 夕実験において，これらに共通な事項を本章にてまとめて 示す。

4.1 シミュレータ装置と評価パイロット 横変位制御 における操縦方法の違い (エルロン方式とラダー方式) が 飛行性にどのような影響を与えるかを, 東海大学工学部航 空宇宙学科所有の固定座席型フライトシミュレータを用い て評価実験を実施した . 第 6 図に炎の構成を示す．このシ ミュレータは, 軽飛行機クラスを模擬したコックピットを 有しており，3 台のプロジェクタから大型 3 面スクリーン に投影される外部視界の視野角は左右 $110^{\circ}$, 上下方向 $26^{\circ}$ である .

また，機体運動の演算には横方向 3 自由度のみの線形微小 擾乱運動方程式を使用した . 計算サイクルは $20 \mathrm{~ms}$ である . 評価パイロットにはテストパイロットとして飛行経験豊 富な 2 名にお願いした .

飛行性の評価データとしては , パイロットレイティング (Cooper-Harper Scale , PR) ${ }^{2)}$ とワークロード (WL) レ イティングを取得した．WL は 10 段階評価（ロール角保 持機能もヨーダンパもない機体をエルロン方式で操縦した ときの WL を基準值「4」とし , 数值が大きくなるほどタ スク達成に労力を要することを表す) とした．また，各フ ライト後には評価内容についてのパイロットコメントを取 得した。

本研究の実験では横飛行経路保持タスクの飛行性評価が 対象である. 光のタスクを行うために，第 7 図に示すよう に，目標飛行経路を表す 4 本のバーをスクリーン上に表示 した .これらのバーは目標飛行経路上に立っており，機体 から弚れ光れ図に示す距離だけ前方に位置している（機体 とともに動く）.これらのバーが一直線上に重なり合って見 


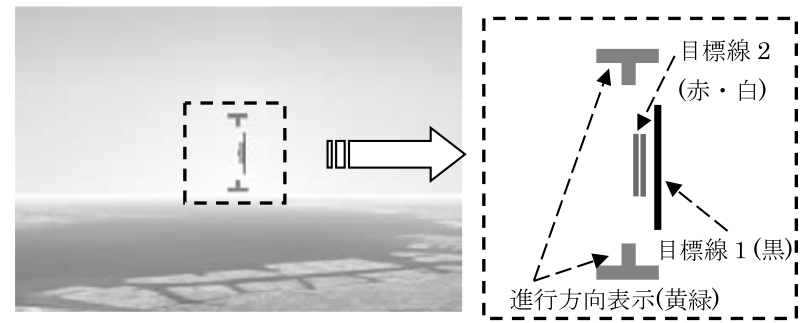

(a) フライトシミュレータ中央画面の表示内容

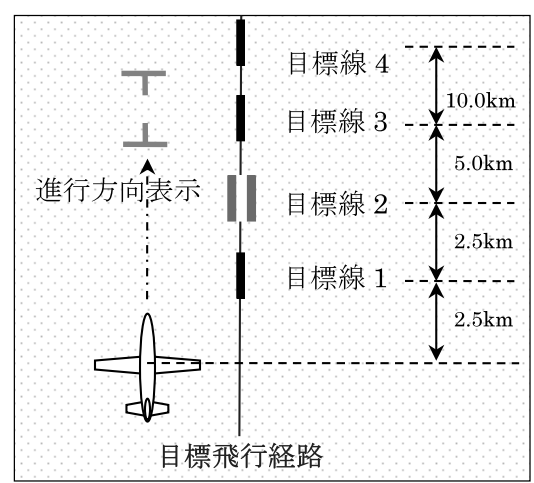

(b) 目標線の配置

第7図 目標飛行経路の表示

えるとき，機体は目標飛行経路上を飛行していることにな る.ラダー方式においてロール角保持機能が㗢くと，パイ ロットは外部視界情報, 特にロール角から機体の進行方向 を予測することが困難になる．弚こで，補助的情報として 航空機の進行方向を表す黄緑色のバー (以下 , ベクトルと 称する) をヘッドアップ・ディスプレイ (HUD) 方式のよ うにスクリーン上に表示して実験を行った .このベクトル は，エルロン方式の場合も利用できるようにした .

4.2 パイロット操作装置 エルロン方式ではパイロット はエルロンを動かし，ラダー方式ではラダーを動かすが， いずれの方式でもパイロットが直接操作する装置は操縦輪 にしている．つまり，ラダーもラダーペダルではなく操縦 輪で操作する . パイロット操作装置を統一することで, 兴 の違いによる影響を除去することができるし，操縦輪操作 (手による操舵) の方がラダーペダル (足による操舵) に比 べ精密な操縦が可能となるためである .

操縦輪操作量 $\delta_{\mathrm{w}}$ からラダー舵角 $\delta_{\mathrm{r}}$ へのギヤ比は, 次の ように設定した . 先ず初期設定值として，操縦輪をステッ プ状に最大限使用したときに発生する方位角 $\psi$ の応答と， ラダーペダルをステップ状に最大限使用したときの方位角 $\psi$ の応答とがほぼ同じ大きさになるように設定した . 次い で予備実験で評価パイロットからこのギヤ比の值で舵効き に問題がないことの確認を得た上で使用した．また，操縦 輪操作量 $\delta_{\mathrm{w}}$ からエルロン舵角 $\delta_{\mathrm{a}}$ へのギヤ比についても同 樣に , パイロットによる事前確認を得ている.

\section{5. 基 礎 実 験}

エルロン方式とラダー方式の基本的な特性の違いを調べ るため実施した実験である。以下，後述の応用実験と区別

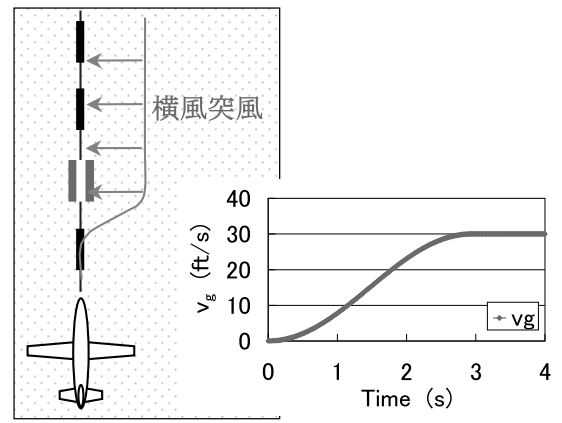

第 8 図 基礎実験 $(2)$ ・横風突風モデル

するために基礎実験と呼称する .

5.1 基礎実験でのタスク 実験タスクとして,パイロッ 卜には所定の飛行経路を保持するタスクを与えた .

基礎実験として下記の 2 種類の目標飛行経路保持タスク 実験を行った。一つは外乱のない状態での純粋な操舵応答 特性に関する評価実験であり，もう一つは外乱を含んだ場 合の評価実験である .

(1) 初期横変位を修正するタスク:目標飛行経路から $20 \mathrm{~m}$ 横の位置で目標飛行経路と平行な水平直線飛行をしている 状態から，できるだけ早く正確に目標飛行経路上を飛行す るように修正し保持するタスクである (第 7 图参照) .

（2）横風突風による経路逸脱を修正するタスク：目標飛 行経路上を飛行している航空機に横風突風を外乱として与 え，光れによって乱された飛行経路を，できるだけ早く正 確に修正するタスクである . 使用した横風突風 $v_{\mathrm{g}}$ は下記の 式で示すように, 立ち上り部が $1-\cos$ 型のステップ状の 突風である (第 8 图参照) .

$$
\begin{array}{ll}
v_{\mathrm{g}}=\frac{v_{\mathrm{CW}}}{2}(1-\cos \omega t) & 0 \leq t \leq \frac{\pi}{\omega} \\
v_{\mathrm{g}}=v_{\mathrm{CW}} & \frac{\pi}{\omega}<t
\end{array}
$$

ここで, 突風の定常値 $v_{\mathrm{CW}}$ は $30 \mathrm{ft} / \mathrm{s}$ とした . $\omega$ はロール 角保持機能もヨーダンパもない機体におけるダッチロール。 モードの固有角振動数と同じ值 $(\omega=1.07 \mathrm{rad} / \mathrm{s})$ とした .

5.2 基礎実験の結果 基礎実験の結果を第 9 13 図に 示す.これらの図中の「RMS」は二乗平均平方根 (Root Mean Square）を意味し， $\left\ulcorner n_{y}\right\lrcorner$ は次式に示すように，機 体重心位置で搭乗者や搭載センサーが感知する機体左右方 向 (機体 $Y$ 軸方向) の加速度を重力加速度て除したもので ある

$$
n_{y}=\frac{U_{0} \cdot(\dot{\beta}+r)-g \cdot \sin \phi}{g}
$$

実験は 2 名のパイロット (A および B) で実施したが， エルロン方式でのラダー使用の程度に差異が見られたもの の, 各方式の評価結果の傾向は同じであった . 弚こで, 本 実験の慣熟飛行を含めた操縦時間が多く，かつ全実験ヶー スにおいてデータ取得したパイロット A の結果を用いて報 告する .

（1）初期横変位修正タスクの結果：本タスクにおける各 


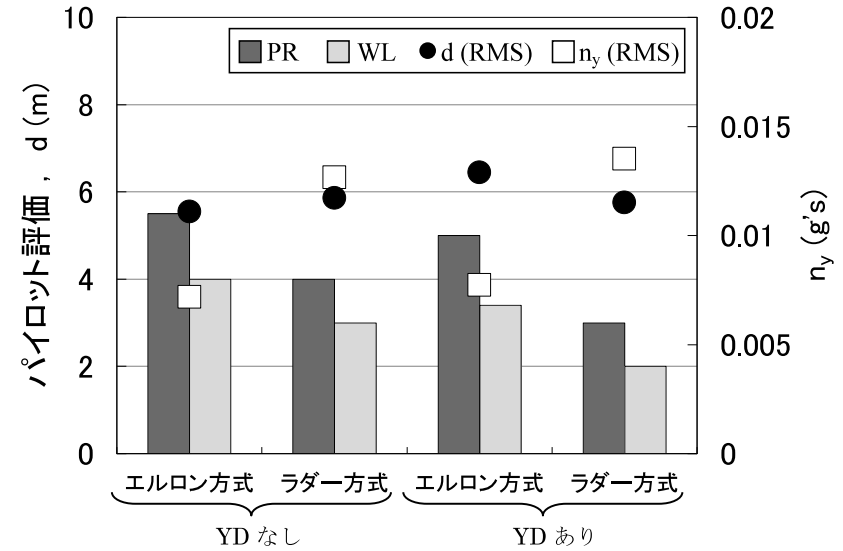

第 9 図 基礎実験 (1)・パイロット評価とタスク性能および横加速度

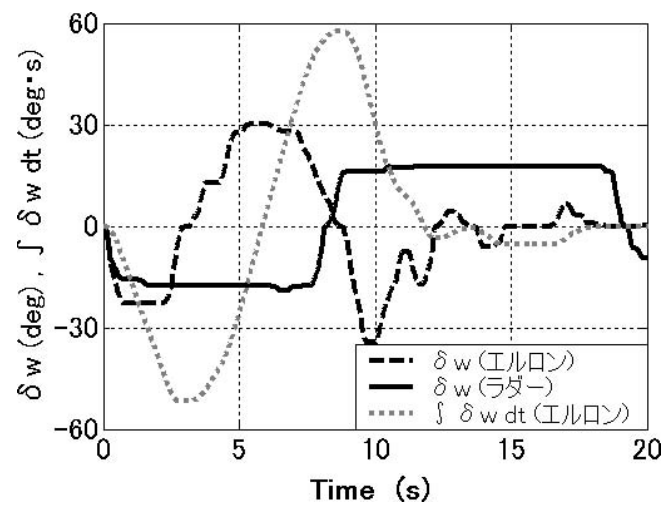

第 10 図 操縦輪操作履歴の比較

方式の実験結果を比較したものを第 9 図に示す . エルロン 方式よりもラダー方式の方がパイロット評価（パイロット・ レイティング PR およびワークロード WL) が良い.ヨー ダンパを作動させるとさらに評価が良くなっている，一方， 目標飛行経路からの横逸脱量 $d$ の RMS 值で表されるタス ク性能を見ると，エルロン方式とラダー方式において大差 ないことがわかる . パイロット評価とタスク性能のみを見 ると, ラダー方式はエルロン方式と比較して , パイロット にとって同程度のタスク性能を得るのに労力も少なく操縦 し易い操縦方式になり得ることを示している .

両方式における操縦性結果の差異の根拠について考察す る.第 10 図は, エルロン方式とラダー方式についてのパ イロット操縦輪操作量の時間履歴であり，参考に兴のうち のエルロン方式の操作量を時間積分した量も追加表示して いる.この図から，ラダー方式の操作量履歴はエルロン方 式の光れと比較して，位相進みが少なく周波数も低いこと がわかる . 兴のラダー方式の操作履歴はエルロン方式の操 作履歴を時間積分したものよりもさらに位相進みが少なく， かつ低周波数の履歴になっているほどである .このことは， ラダー方式の方が横変位発生までに積分要素が少なくとも 1 個以上少ないことを示しており，パイロットの位相進み補 償操作か軽減されることを説明してくれるものである．ま た，この結果は第 2 章で近似的に得た積分要素数の違いと 対応している。

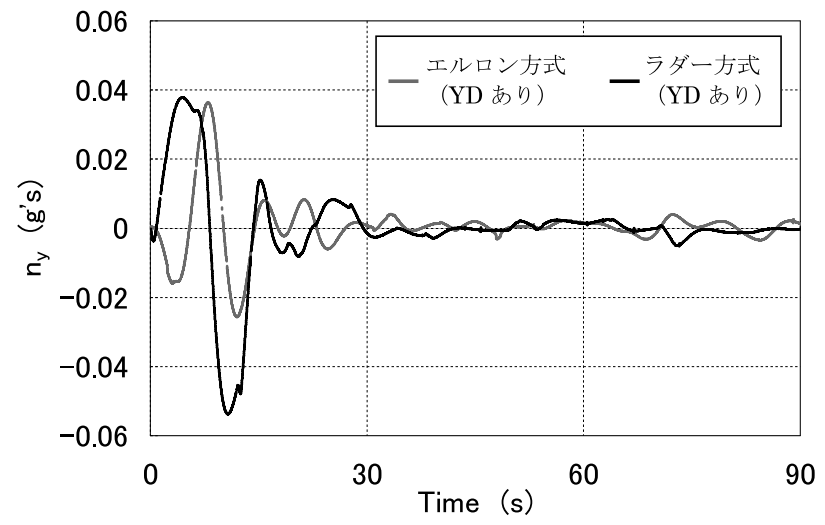

第11図 横加速度の比較

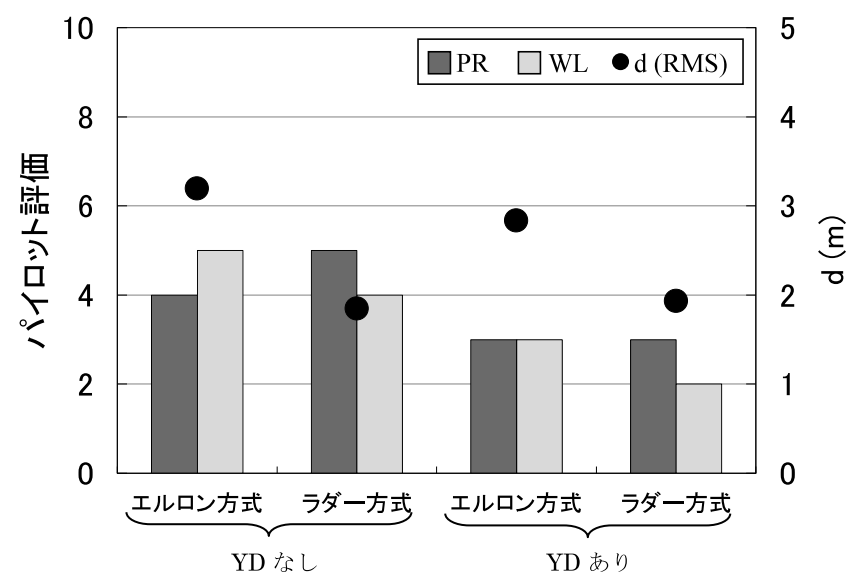

第 12 図 基礎実験 $(2) \cdot$ ・ペイロット評価とタスク性能

次に横加速度発生量について考察する . 横加速度の発生 量 $n_{y}$ の RMS 值はヨーダンパの有無にかかわらず，エルロ ン方式の方が $40 \%$ 程度小さくなった (第 9 図参照) .このよ うな結果になった原因は，エルロン方式においては釣り合 い旋回を基本としながら経路を変更するのに対し，ラダー 方式では横滑りによって発生する横力て経路を変えるといっ た違いによる.ここで, 第 11 図にエルロン方式とラダー方 式 (ともにヨーダンパあり) における横加速度 $n_{y}$ の時系 列データを示す.第 11 図において $n_{y}$ の最大振幅を見ると， エルロン方式では約 $0.035 \mathrm{~g}$ 's であるのに対し，ラダー方 式では約 $0.05 g$ 'sである .ここで, ラダー方式における $n_{y}$ の最大振幅の值は，ロール角を約 $3 \operatorname{deg}$ に保持しながら定 常横滑り飛行する際にパイロットが感じる横加速度とほぼ 同じ大きさであり，操縦性に大きな影響を及ぼすほどの值 ではないと推測される . また ,地上コックピットにおいてパ イロットが操縦する無人機においては，モーションキュー の影響を無視できるため, ラダー方式は有効な操縦方法と なり得る . 今回の評価実験は固定座席型シミュレータを使 用したため，モーションキューを与えた状態での操縦性へ の影響を把握していない．よって今後はモーションキュー を与えた状態で, 評価実験をする必要があると考えている．

（2）横風突風時の経路保持タスクの結果：本タスクにお ける各方式の実験結果を比較したものを第 12 図に示す.エ 
ルロン方式とラダー方式とのパイロット評価 (PR と WL) の差異はあまり明確ではないが , ラダー方式の方の WL 值 が小さくなっており，パイロットの作業負担か軽減されて いることが伺える．また，方式よりもヨーダンパを付ける ことによる効果の方が明確であり, パイロット評価が最も 良いのは，ヨーダンパ有りのラダー方式のときである.方, タスク性能については, ラダー方式の横変位逸脱量 $d$ の RMS 值がエルロン方式の光れと比較して明らかに小さ くなっており，ヨーダンパの有無にかかわらず性能が良く なっている．以上のことから，横風突風を受けたとき，ラ ダー方式はエルロン方式に比べて，操縦性評価は光れほど 差異か認められないけれども，飛行経路保持のタスク性能 が改善されることがわかる.前項 (1) に示した初期横変位 修正タスクでの実験結果とは対照的な結果になっている .

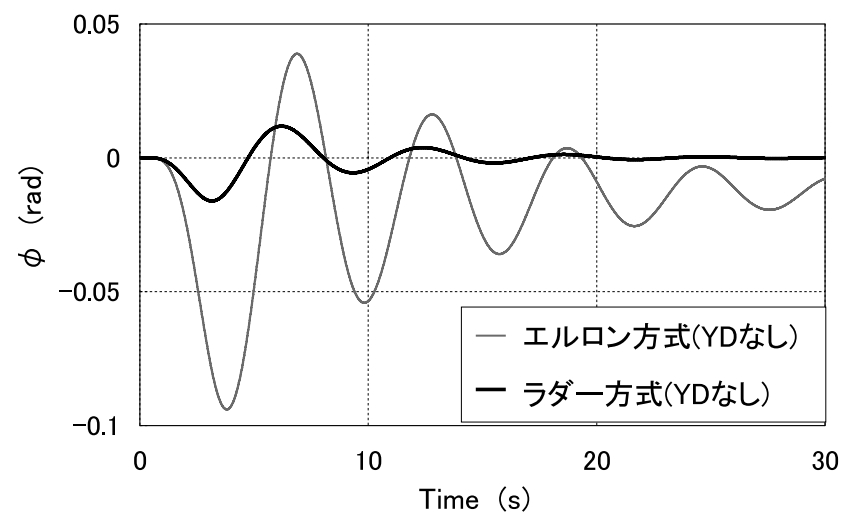

(a) 横風突風によって生じるロール角の応答

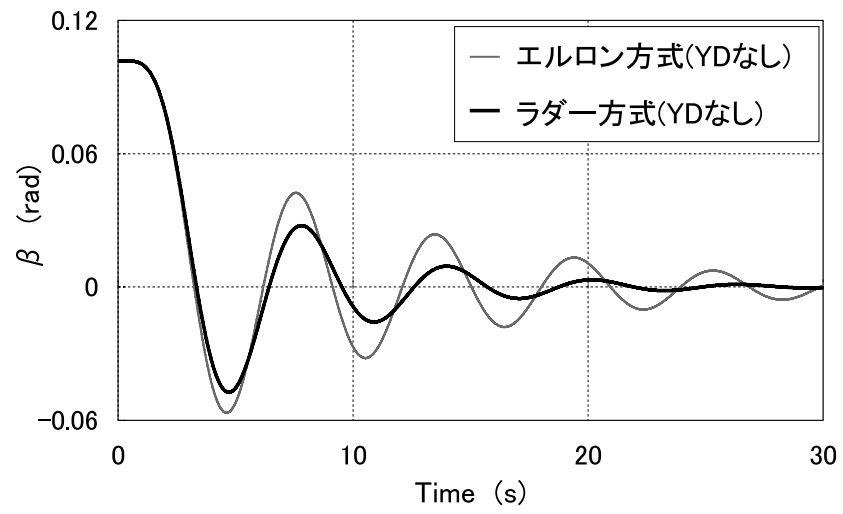

(b) 横風突風によって生じる横滑り角の応答

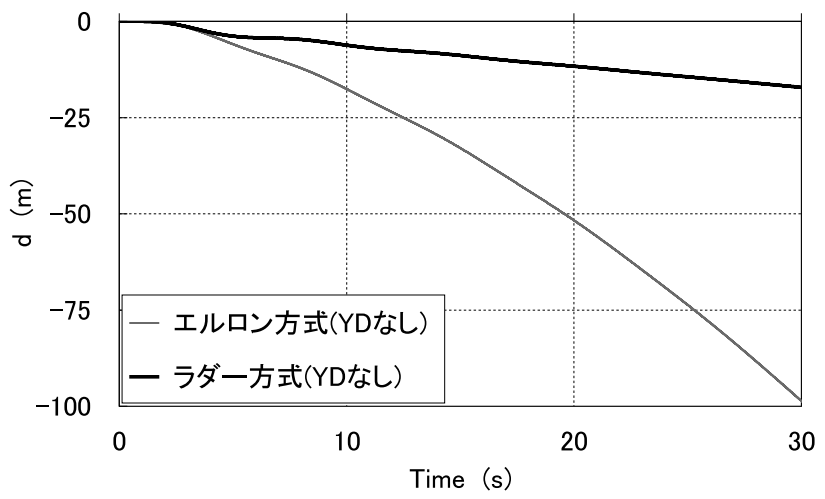

(c) 横風突風によって生じる横変位の応答

第 13 図 横風突風による機体応答
ラダー方式の場合に飛行経路保持タスク性能が改善する 理由は下記のように説明できる . 先ず , パイロットによる 操舵入力が無い状態で, 上記実験タスクと同じ大きさの純 ステップ型の横風突風を外乱として与えたときのロール角， 横滑り角, 横変位の機体応答を第 13 図に示す.ラダー方式 の場合は，エルロン方式の場合に比ベ ， ロール角のダッチ ロール振動成分の大きさが小さく，かつ時間が経過すると ロール角がゼロに落ち着いている．また，横滑り角におい てもラダー方式の方が早くゼロに落ち着いている .これら はラダー方式の場合，内蔵されているロール角保持機能に よって, 横風を受けても上反角効果によって煽られるロール 運動が抑えられて流されにくくなるとともに，風見安定効 果によって速やかに横滑り角ゼロのクラブ姿勢になるため に，目標飛行経路からの逸脱量が小さくなることを示して いる.即ち，横風突風時におけるタスク性能改善の理由は 舵面としてエルロンを用いるかラダーを用いるかではなく， ラダー方式がロール角保持機能を有していることに拠る．

\section{6. 遷移方式と応用実験}

6.1 遷移方式の設定 上述の基礎実験によって，横飛 行経路保持タスクにおけるラダー方式の潜在的な有効性の 存在か確認された。しかしながら，このラダー方式の有効 性が発揮されるのは, 飛行経路からの横逸脱量が比較的小 さい範囲にある場合に制限されることがパイロットコメン 卜から明らかになった . 弚の内容は次のようなものである. 横飛行経路からの逸脱量が大きい場合, 初めに機体を目標 飛行経路に近づけるときはフィードフォワード的な操舵と なり，目標経路付近に達したあとはフィードバック的な修 正操舵となる . ラダー方式は後者の操舵には有効であるが， 前者の操舵には従来の操舵方式であるエルロン方式が適し ている．本実験の機体の場合，ラダー方式が有効な限界は 目標飛行経路からの横逸脱量が約 $\pm 20 \mathrm{~m}$ 程度である.

以上のパイロットからのコメントを参考にして，実用的 な操縦方式に近づけるために，下記のようなエルロン方式 とラダー方式とを組み合わせた方式（以下，遷移方式と呼 称する) を設定した . 第 14 図に示すように，遷移方式では

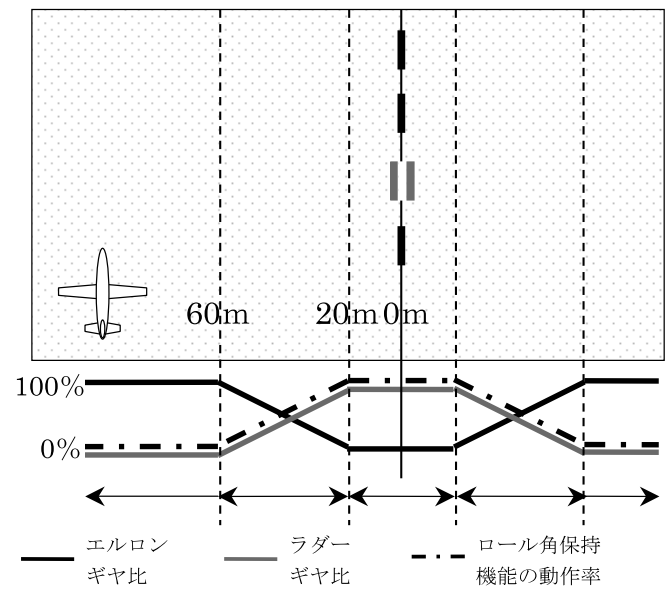

第 14 図 遷移方式・横変位量と操縦方式 
第 4 表 飛行制御システムのゲイン一覧 (応用実験)

\begin{tabular}{lllcl}
\hline & $K_{\phi}$ & $K_{p}$ & $K_{r}$ & $\tau_{r}(\mathrm{~s})$ \\
\hline エルロン方式-YD & 0 & 0 & 1.031 & 4.8 \\
遷移方式(1)-YD & 0.8 & 3 & 0.726 & 2.09 \\
遷移方式(2)-YD & 0.07 & 0.66 & 0.875 & 2.47 \\
\hline
\end{tabular}

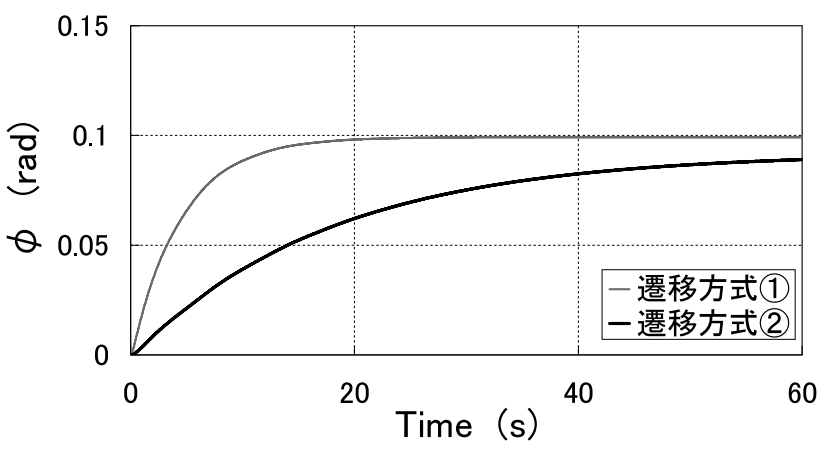

第 15 図 ロール角保持機能の強さの比較

第 5 表 横方向の飛行パラメータの比較 (応用実験)

\begin{tabular}{lccccc}
\hline & $\zeta_{\mathrm{d}}$ & $\begin{array}{c}\omega_{\mathrm{nd}} \\
(\mathrm{rad} / \mathrm{s})\end{array}$ & $\begin{array}{c}\zeta_{\mathrm{d}} \omega_{\mathrm{nd}} \\
(\mathrm{rad} / \mathrm{s})\end{array}$ & $|\phi / \beta|_{\mathrm{d}}$ & $\phi_{\mathrm{ss}} / \delta_{\mathrm{r}}$ \\
\hline エルロン方式-YD & 0.4 & 0.95 & 0.38 & 1.24 & -0.83 \\
遷移方式(1)-YD & 0.4 & 0.93 & 0.37 & 0.31 & -0.01 \\
遷移方式(2)-YD & 0.4 & 0.95 & 0.38 & 0.79 & -0.07 \\
\hline
\end{tabular}

目標飛行経路からの逸脱量が $60 \mathrm{~m}$ 以上のときは操縦輪操 作に対して $100 \%$ エルロンのみが動き，逸脱量が $20 \mathrm{~m}$ 以下 のときは $100 \%$ ラダーのみが動作される. 弚して逸脱量が $60 \mathrm{~m}$ から $20 \mathrm{~m}$ に近づくにつれて, 操縦輪操作に対するエ ルロン動作比率が $100 \%$ から $0 \%$ ，かつ操縦輪操作に対す るラダー動作比率とラダー方式に内蔵されているロール角 保持機能が $0 \%$ から $100 \%$ (正確にはロール角保持システ ムのゲイン $K_{\phi}$ と $K_{p}$ の值が 0 からラダー方式での設定值 へ) と線形に変化するように設定した .

6.2 応用実験とその結果 この遷移方式の有効性を従 来の操縦方式であるエルロン方式の光れと比較するため， フライトシミュレータ実験を実施した . 以下，これを応用 実験と呼称する . 応用実験は基礎実験の場合と同じシミュ レータ装置を用い，同じ評価パイロットによってなされた . パイロットに与えた飛行タスクは初期横変位を $100 \mathrm{~m}$ とし た初期横変位修正タスクである。

応用実験を行うにあたり，パイロットより「エルロン方式 からラダー方式に切り替わる際，ロール角保持機能か強す ぎると違和感を覚える」との指摘を受けた . 乥こで, 応用実 験においてはエルロン方式からラダー方式に切り替わる際 に，ロール角保持機能を弱く設定したものを新たに追加し た .ラダー方式でのロール角保持機能が基礎実験と同じ強 さのものを「遷移方式(1)」と，新たに追加した保持機能を弱 〈設定したものについては「遷移方式(2)」と呼称することに する.遷移方式において完全にラダー方式に切り替わった領 域でのゲイン等の設定値を第 4 表に示す. 遷移方式(1) と (2) におけるロール角保持機能の強さの比較を第 15 図に示す． 第 15 図は, ステップ状にロール角コマンド $\phi_{\mathrm{C}}=0.1 \mathrm{rad}$ を与えたときのロール角の応答である . また , 第 5 表にエ

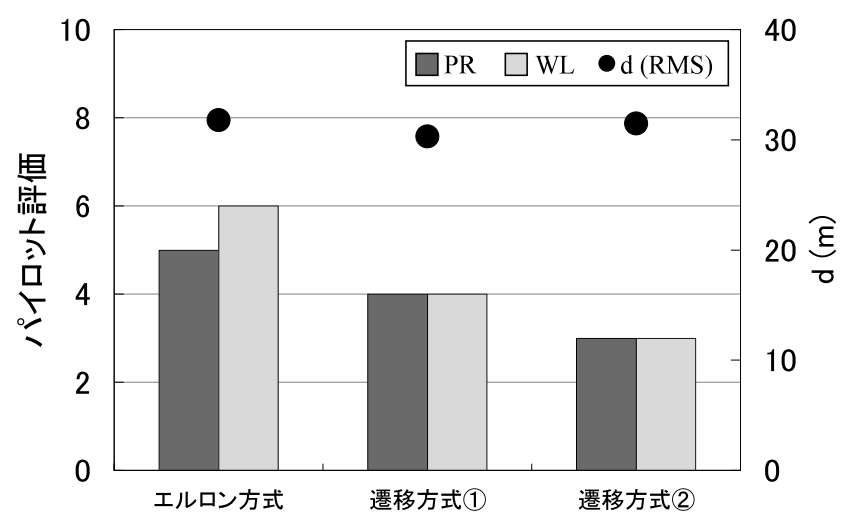

第 16 図応用実験・パイロット評価とタスク性能

ルロン方式と遷移方式 (完全にラダー方式に切り替わった 領域) におけるダッチロール・モードの減衰率 $\zeta_{\mathrm{d}}$ と固有 角振動数 $\omega_{\mathrm{nd}}$, ダッチロール・モード成分の振幅比 $|\phi / \beta|_{\mathrm{d}}$, およびラダーステップ入力に対するロール角 $\phi$ の定常值の 比 $\phi_{\mathrm{ss}} / \delta_{\mathrm{r}}$ を示す.

6.3 応用実験の結果 応用実験の結果を第 16 图に示す。 パイロット評価が最も良いのは, 遷移方式(2)のケースであ る. エルロン方式とラダー方式の違いについてパイロット は,「エルロン方式の場合, 当て舵のタイミングを間違え るとオーバーシュートするときがある. 弚れに対し, 遷移 方式では目標経路から遠いときは迅速に運動できるし，経 路付近になると適度にロール角が小さく収束してくれるの で機体の動きを把握しやすく，結果としてオーバーシュー トしにくくなった」とコメントしており，遷移方式の方が 従来方式 (エルロン方式) よりも操縦しやすいことを明確 に指摘している．また，前述の通り「エルロン方式からラ ダー方式に切り替わる際, ロール角保持機能が強すぎると 違和感を覚える」ともコメントしている . 応用実験でのエ ルロン方式からラダー方式への遷移を含む総合タスクでは， ラダー方式のロール保持機能がある程度弱い方がパイロッ 卜にとって感覚的に円滑に遷移できる結果となった．

一方, タスク性能 (横变位制御の正確さ) については工 ルロン方式，遷移方式(1)おひひ遷移方式(2)の間で明確な差 異は見られなかった (第 16 図参照).

$$
\text { 7. ま と め }
$$

目標飛行経路からの横逸脱をゼロにする飛行経路保持夕 スクにおいて，従来からのエルロンを主体として操縦する 方式 (エルロン方式) の代わりに, ロール角保持システムを 作動した状態でラダーを操縦舵面として使用する方式 (ラ ダー方式）を考案して，フライトシミュレータ実験により 兴の有効性について検討した . 両方式ともパイロットが操 舵入力を加える操作装置は操縦輪としている. 兴の実験の 結果, 主として下記のことが明らかになった .

(1) 目標飛行経路付近 (横変位 $20 \mathrm{~m}$ 以下) では, ラダー 方式とエルロン方式とでタスク性能にほとんど差が見られ ないのに , 操縦のしやすさを示すパイロット評価はラダー 
方式の方か明確に良かつた . 応答時間履歴データからは, ラ ダー方式のパイロット操舵の周波数がエルロン方式の光れ よりも低く, 操舵に要求される進み操作の低減が見られた。 このことは, 操舵入力から機体の横変位応答が発生するま でのプロセスにおいて純粋な積分要素が 1 個少ないことに 対応している。

（2）横風突風によって乱された経路を修正するタスクに おいても，ラダー方式に内蔵のロール角保持機能によって 機体が突風に流されにくくなり，タスク性能か改良された。

(3) 目標飛行経路からの横逸脱量が大きいときは従来の エルロン方式を用い, 目標飛行経路に近づくと徐々にラダー 方式に遷移していき，目標飛行経路付近では完全にラダー 方式に移行するより実用的な方式（遷移方式）においても， 兴の有効性がシミュレータ実験によって確認された．遷移 方式では，ラダー方式に移行する際にロール角保持があま り強くない方が良いという結果が得られた .

(4) 以上の結果をまとめると, 通常の有人機や地上コック
ピットを用いて操縦する無人機において，横飛行経路保持 タスクにおけるラダー方式の有効性が見出せた . なお，有 人機の場合は，横加速度の発生による乗り心地への悪影響 が懸念される．今後，実機での飛行試験あるいはモーショ ンベース型シミュレータでの評価実験の実施が課題である と考えている。

本研究におけるフライトシミュレータ実験の実施にあた り，海上自衛隊第 51 航空隊の藤倉昭夫氏，渡邊清隆氏お よび平野吉高氏にこ指導をいただいた .ここに感謝の意を 表す。

$$
\text { 参 考 文 献 }
$$

1) 加藤宽一郎, 大屋昭男, 柄沢研治: 航空機力学入門, 東京大学出 版会, 東京, 1982, pp. 103-109, 199-200.

2) Cooper, G. E. and Harper, R. P.: The Use of Pilot Rating in the Evaluation of Aircraft Handling Qualities, NASA TN D-5153, 1969. 